\title{
The dynamic process of motivation to learn Czech in study abroad courses
}

\author{
Silvie Převrátilová
}

\begin{abstract}
This article presents research on the motivation and attitudes towards learning Czech among students in the Czech language courses within the study abroad programmes at Charles University (Erasmus+ and US Study Abroad). This research was carried out in three consecutive steps. Their secondary aim was to evaluate the data collection tools for the following phases and future research. The participants were students who come to Charles University usually for one semester in the length of 13 weeks taking a Czech course with lessons twice a week. In the first stage of the study, 174 students in the US Study Abroad participated in a questionnaire survey aiming at determining whether there is a change in attitudes towards learning Czech and what the sources of their motivation are. The second stage focused in more detail on 12 students in this programme: analyses of their diaries written for 12 weeks helped create a motivational profile from the perspective of L2 Motivational Self System (L2MSS, Dörnyei, 2005, 2009) and point out key motivational factors, which were the learning experience and desire to interact with Czech people. Diary study was also used as the data collection tool together with questionnaires and an interview in the third stage, with two French students in Erasmus+ programme. The motivational profiles of Erasmus+ students have also shown the remarkable role of the L2 Learning Experience. The findings have also led to some pedagogical implications relevant for this type of course.
\end{abstract}

Key words: Czech as a foreign language; diary studies; L2MSS; motivation; study abroad

\section{Introduction}

Study abroad as a language learning context has been researched for decades, with the primary focus on the correlation between studying abroad and one's gain in linguistic competence (Carroll, 1967; Freed, 1995; Kinginger, 2008). Among other areas of interest: identity, change in beliefs about language learning, and motivation were the most widely examined topics. In the research carried out so far, the English language, unsurprisingly, receives the most attention. Among languages other than English (LOTEs), researchers focus on widely taught languages such as Spanish, French, or Russian. Small languages, such as Czech, are still rather understudied (Boo et al., 2015). Very little is known about the students' motivation to learn Czech (Sieglová, 2008), the sources of motivation, and factors driving potential change in attitudes towards learning Czech. As Dörnyei \& Ushioda (2017) point out, motivation to learn a small language is likely to be different from the motivation to learn big languages and this may impact the way it should be taught in certain contexts, e.g. study abroad.

This paper examines the motivation and attitudes towards learning Czech among students at Charles University, Prague. The study presented here covers the in- 
troductory phase of the larger-scale research on this topic going on at the time when this paper was written. This introductory phase was carried out in three consecutive steps. Their secondary aim was to evaluate the data collection tools for the following phases and future research.

Two study abroad programmes were examined in this study: Erasmus+ and American Study Abroad. Many students in study abroad programmes take Czech language classes, either voluntarily, or as part of their compulsory syllabus. Unlike students who decide to study in a foreign country to achieve a higher linguistic competence, it is possible that many students coming to the Czech Republic only want to learn Czech to enhance their study abroad experience while staying here. Finding out how motivation changes and what the sources of motivation are for these students may help determine appropriate pedagogical strategies for such classes.

First, the theoretical framework of the L2 Motivational Self-System will be discussed, followed by the results of empirical research carried out among students in the Czech beginner courses at Charles University, Prague. The research comprises three stages so far. They served as pilot studies for the following phases of the motivational research at Charles University. The aim of the pilot studies was two-fold: 1 . to examine the motivational profiles of the students, and 2. to test the suitability of the data collection tools (questionnaires, journals, and interviews) for the following research in these two programmes. This paper will focus mainly on the qualitative study of two students in the third stage. The questionnaire survey among American students (stage 1) and the diary study in the same study context (stage 2) will only be described briefly to present the full picture as they were fully described in separate articles (Převrátilová, 2019, 2020).

\section{L2 Motivational Self System (L2MSS)}

There are dozens of theoretical approaches to motivation in psychology and several have found its place in applied linguistics (for an overview, see Dörnyei \& Ushioda, 2011). Two of them seem to play a more significant role in recent research (Boo et al., 2015): the first is Gardner's socio-educational model (Gardner, 1985,2009 ) with the integrative and instrumental dichotomy perhaps being the most widely spread concept of motivation, where integrativeness is based on the attitudes toward the target language community and the need to interact with them or become similar to them, whereas instrumentality relates to practical reasons to learn the language, such as getting a good grade on the transcript. The second widely used framework is Dörnyei's L2 Motivational Self-System (Dörnyei, 2005, 2009) where Dörnyei synthesizes the existing approaches to motivation, among others including Gardner's model as well as the well-known concept of extrinsic and intrinsic motivation (Deci \& Ryan, 1985), and connects them to the 
current trends in modern psychology. The core of the L2MSS lies in the theory of possible future selves (Markus \& Nurius, 1985): individual's image of an Ideal L2 Self - in our research, it is the image of the student speaking Czech with local people - and "the attributes that one believes one ought-to possess to meet expectations and avoid negative outcomes" (Dörnyei \& Ushioda, 2011, p. 86), which create the Ought-to L2 self. Dörnyei added a third component, the L2 Learning Experience as motives relating to the specific learning situation, such as the impact of the teacher, course, classroom activities, etc. This relatively new model of language learning motivation does not reject the previous ones, it rather aims at creating an "umbrella" concept for them. For example, Gardner's integrative motivation finds its place under the Ideal L2 Self, whereas the instrumental one would represent the Ought-to L2 Self. Similarly, the notion of extrinsic and intrinsic motivation mentioned above find their place here: the former one in the Ought-to L2 Self and the latter in the Ideal L2 Self.

In relation to the multilingual turn in applied linguistics, some authors criticise the "monolingual bias" and call for the multilingual perspective of research (Cook, 2016; Douglas Fir Group, 2016; Franceschini, 2011; Henry, 2017; Ortega, 2013). Therefore, the L2 Motivational Self-System might be adapted to the Multilingual Motivational Self-System. This is a particularly valid idea in the framework of Czech language research since Czech is never the first L2 of the students in the target group.

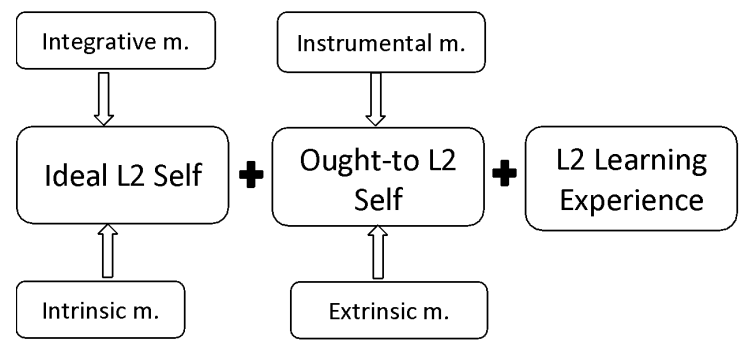

Diagram 1: L2 Motivational Self-System (Dörnyei, 2005, 2009)

\section{Empirical study at Charles University, Prague}

The research presented in this article targets university students coming to study in Prague in two contexts. The first one is the American UPCES study abroad programme organised by the CERGE-EI foundation and the second one is Erasmus+ at the Faculty of Humanities, both at Charles University, Prague. The aim 
was two-fold: 1. to find out whether and how motivation to study Czech changes throughout the semester and whether these two contexts differ in the area of student motivation; 2. to assess the suitability of the data collection tools for future research.

American students in the UPCES programme were examined first. This stage has been fully described in a separate article (Převrátilová, 2019) therefore, only the essential information relevant for this paper will be repeated here. An introductory survey was carried out among 174 students in compulsory Elementary Czech courses (average age 21) at the end of the semester (13 weeks). The results of the study have shown that there is a substantial change in the attitudes of these students. At the start of the semester, most students expressed a certain level of uncertainty and anxiety, whereas at the end, their attitudes were positive. The key factors affecting motivation and attitudes were related to the classroom experience (teacher, method) and the need to communicate with the target language group.

These findings were used to create hypotheses for the following qualitative stage of the research, where the same sample of students (not the same students but the following semester in the same programme) wrote their Czech language learning journals for a semester (for a methodological overview of diary studies in applied linguistics see Bailey, 1983). We expected that the initial attitude would be rather negative or mixed and that it would undergo a certain change and that the final attitude would be positive. The L2 Learning Experience was expected to play a central role as a source of motivation, together with the Ideal L2 Self represented in the need to communicate with the Czech people. For several weeks at the start of the semester, students wrote their journals at the end of each lesson, and then they could choose whether they wanted to continue or not. For the qualitative analysis of the diaries, twelve diaries were chosen (for the specific selection criteria and other details of the diary study, see Převrátilová, 2020). The results confirmed the dynamic nature of motivation and similarly to the quantitative survey, the key factors from the students' perspective related to the L2 learning situation. Furthermore, a strong desire to communicate with the target culture and affective states relating to the learning process, such as tiredness, boredom, or entertainment, played a significant role. These diaries helped create a tentative motivational profile of the American students in Prague, which shall be contrasted to the other educational context - Erasmus+ at the Faculty of Humanities, Charles University, in the following stage of the research.

To summarise what we have learned in the first two steps of our research:

1. The motivation of students in the US programme seems to go through a significant change from rather negative or mixed attitudes to positive ones. 
2. From the L2MSS perspective, the main sources of their motivation are the L2 Learning Experience and the Ideal L2 Self with the need to interact in the local language playing the prominent role.

3. Diaries do provide sufficient data. However, the content is not always linked to the research question relating to motivation directly. Therefore, in the following stages of research, interviews should be used to receive a wider range of data on motivational changes and students' attitudes.

The question for the next stage was whether the motivation of students in the Erasmus+ programme follows a pattern similar to the US students. The relevance of interviews as a data source and their contribution to the research design was also going to be tested.

\section{Diary study on motivation to study Czech in the Erasmus+ programme}

The diary study in Erasmus+ aimed at testing the research design (diary and interview). Among students who decided to participate in the diary study, two students completed a full academic year of journaling and participated in the final interview. They were not the only students who completed their journals, but they were the only ones who were interviewed. Since the secondary aim of each stage was to test the data collection tool, the data gained from these two students were analysed. Luisa and Luke (their names have been changed) attended the optional Czech for Beginners course taking place twice a week (eighty-minute lessons) followed by a second semester Czech course of the same intensity. Each semester took thirteen weeks of class with an exam period of five weeks in between.

Luisa and Luke both journaled the whole academic year (typed and handed in the journals electronically at the end of each semester), filled in a questionnaire, provided their letter of motivation to participate in Erasmus+ at Charles University, and took a final interview with the researcher, who was also their Czech language teacher in both semesters. The transcription of the interview and data analysis with the help of the Atlas qualitative analysis software provided the basis for the motivational profile of each participant.

\section{Motivational profile: Luke}

Luke was in his third year as a history major at his home university. He was 23 years old. His mother tongue is French. Czech was his fifth foreign language (after English - B2, Italian - B1, Chinese - A1, and high school Latin). In the future, he would like to learn German and Arabic. He came to Prague because he is interested in central European studies and culture. 
Luke thinks that language is an important tool to understand people not only in every-day communication but also to grasp the way people think and how they perceive the world. In his opinion, language is a unique means to find out about the target culture. Before coming to the Czech Republic, he tried to learn basic phrases such as greetings and thanks and pronunciation rules. In his introductory journal entries, a strong integrative motive stands out: "I think in the end I'll be able to, at least, be independent for the everyday life in Prague without the need to use a translating guide or anything of that sort", which regularly re-appears in his journal throughout the whole academic year.

The content of the Czech lessons, with specific emphasis on grammar and vocabulary, are commented on most frequently. Sometimes, pronunciation is mentioned. Tests and exams seem to be important to Luke. He talks about them several times, although there were only two in each semester. Luke also evaluates the teaching method, which he seems to be slightly uncomfortable with: "I can appreciate the variety of exercises and the effort to not make learning redundant, but I am a little old school and I admit I'd sometime rather do something more conventional. More writing, more speaking, more reviewing. But everybody seems to have fun with this method, so I guess it just does not fit me," and elsewhere: "The lesson was a little more conventional, which I quite liked." Besides methodology, he writes about group dynamics, relationships among the students, and linguistic competence of his classmates: "Interacting with the other students as fluidly as possible, is difficult but however nice; With other students, we remarked that the course seems more fluid and enjoyable than during the last semester, and we wondered if it was because we were fewer students; maybe in smaller groups it is easier to work fast and efficiently." His notes are often extended by comments on emotions and the affective state he is currently experiencing, most frequently it is being tired: "It is satisfying to finally met the last tense we missed so far, and it will prove useful to express ourselves. The class was quite agreeable since it was mainly trying to memorize the construction of the future and pronunciation; it was nice since I felt pretty tired today and I was not ready to start really complex exercises or learning a lot of vocabulary," tiredness re-appears in many journal entries in Luke's journal: "This week-end was quite tiring so frankly I was not at my best this noon; Everybody seems a little tired; the fact that I am a little tired may not help much."

From the perspective of L2MSS, all three components (Ideal L2 Self, Ought-to L2 Self, and L2 Learning Experience) are represented in Luke's motivational profile. The Ideal L2 Self appears as a strong desire to interact in Czech outside of class: "That is quite useful when I'll have the occasion to hang out with friends to try the local dishes; I'll try to go to the bakery tonight and test my knowledge by speaking only Czech, I guess it may be a good training for both my learning of the language and to get out of my comfort zone." The Ought-to L2 Self is in his case related mainly to the need to succeed academically, where the Ideal L2 Self and the Ought-to L2 Self 
are inter-connected: he wants to succeed and at the same time is afraid of failure and therefore, he tries to develop some strategies to avoid the failure.

The third component, the L2 Learning Experience, is the strongest motivating factor for Luke as we have seen above where specific elements such as methodology, class content, and classroom dynamic were commented on. The ratio of the three L2MSS components is presented in diagram 2.

\section{LUKE: L2MSS}

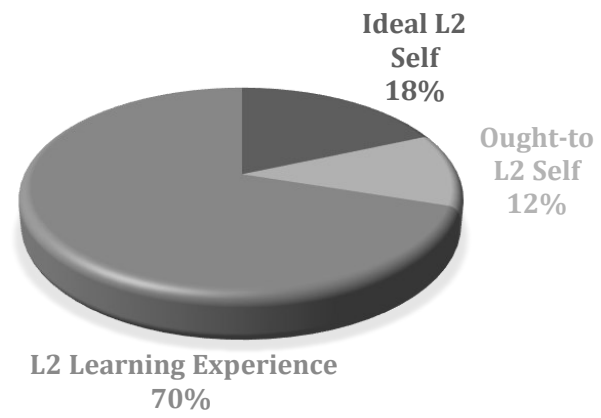

Diagram 2: Luke's motivational profile from the L2MSS perspective

\section{Motivational profile: Luisa}

Luisa was in her first year of the International Studies programme at her university. She was 22 years old. Her mother tongue is French, and she has previously studied English - B2, Spanish - B1, and Chinese - A1. Czech was her fourth foreign language. She had been to the Czech Republic before her Erasmus+ studies: she visited Prague with her parents at the age of 14 and she loved the city and found the Czech language appealing (as a souvenir she bought a magazine in Czech and tried to read).

In her Erasmus letter, she wrote that learning the Czech language was one of her reasons to study in Prague: "It is the occasion to become familiar with a new language, Czech which is a very interesting skill in regard to my career." She wanted to learn a language different from those she had studied before and sought to familiarise herself with the target culture. For Luisa, similarly to what Luke said, language is a tool to understand the culture of the country where she was about to spend the following nine months. Luisa's overall attitude towards learning languages is very positive: "I love learning new languages," although in her journal she says she had to study very hard in the language courses she took. Nevertheless, 
her results were not as good as those of other pupils. Due to her rich previous language learning experience, she realises the amount of effort she will need to invest in the process. Her initial goal was to learn at least a little: "I hope I could speak a bit of Czech by the end of the semester."

As in Luke's case, the strongest motivational element for Luisa is the L2 Learning Experience with an emphasis on the classroom experience and its specific aspects. Emotions linked to the experience play an even more important role for Luisa than they did for Luke. She frequently relates her emotions to the class and its content: "Mentally tired, impossible to think or to speak English. I had a very bad feeling after the class"; "It was interesting, I really enjoyed the class;" and to her experience outside the class: "I can recognize a lot of words in the daily life ... or even when I heard people speaking Czech! I am very proud of myself for that." Her journal entries often contain remarks on her affective state and cognitive overload: "I did not have time to think about the lesson because everything was fast, and I felt lost"; "This class was first absolutely exhausting and then very nice; I am not feeling well today, maybe this is why the class was so difficult." The cognitive overload often relates to two language elements: grammar and vocabulary: "We have seen so many new words; I am a bit lost with these new grammatical rules; So much new information." Besides grammar and vocabulary, Luisa also comments on pronunciation.

Two other significant factors represented in her journal are her learning strategies when she reflects on her previous language learning experience and contrasts it to the current one, and her classmates. Several times she mentions specific people and compares her linguistic competence to theirs, she reflects pair-work and group-work with certain classmates: "There are a lot of good students in the class they inspired me!; I think it is good that my partner was nor French neither from Britain. ... helps me to make greater progress; It is very nice to be a kind of group like that."

The language course is linked to Luisa's Ideal and Ought-to L2 Selves. She realises the effort she needs to make in order to achieve the results she strives for: "I have to study and learn hard not to be lost in Czech classes; I realized I need a lot of time to learn; I need several lessons; I know it will be much harder soon," with occasional comments on learning strategies she is taking towards the test and exams: "Ireally have to revise the oral part for the exam. I am not feeling ready." Nevertheless, the strongest element in her motivational profile is the L2 Learning Experience as we have seen above. The ratio of the L2MSS components in Luisa's motivational profile is presented in diagram 3 .

\section{Discussion and Conclusion}

As demonstrated by Dörnyei \& Ottó (1998) in their process model of motivation, similarly to other language learners' motivation, Czech language students' motiva- 


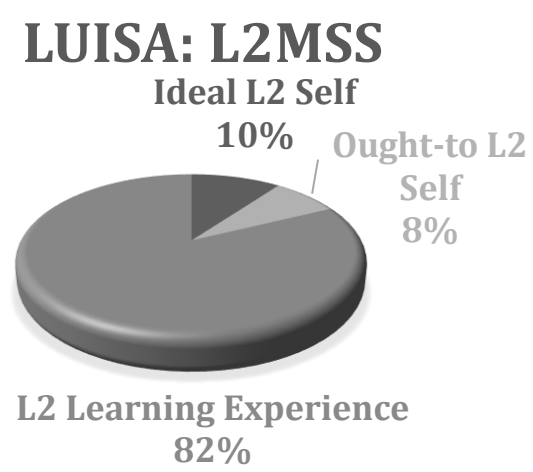

Diagram 3: Luisa's motivational profile from the L2MSS perspective

tion goes through a variety of stages, with the motivational shift more significant in the first group where the American students take the language course mandatorily and have a weaker Ideal Multilingual Self in general.

The L2MSS as a theoretical model has shown the relevance of all its three components (Ideal L2 Self, Ought-to L2 Self, and L2 Learning Experience) in the empirical study. In line with current motivational research findings (Dörnyei, 2019) which show the strong potential of the L2 Learning Experience, all the motivational profiles created in this study express the remarkable prevalence of the L2 Learning Experience as the strongest motivational source out of the three components of the L2MSS for students learning Czech during their study abroad, as both Luke's and Luisa's profiles in diagrams 2 and 3 confirm. This result highlights the unique role of the classroom and the teachers in increasing the students' positive attitude towards the target language and the Ideal Multilingual Self. Therefore, motivational strategies should be used in the classrooms to support students' motivation as Guilloteaux \& Dörnyei (2008) suggest. Dörnyei (2001) or Dörnyei \& Kubanyova (2014) may be used as a springboard for teachers who wish to become more familiar with motivational language teaching.

The second key component of the L2MSS proved the Ideal L2 Self, represented by the internal desire to interact with Czechs and getting to know the local culture. The reason for the prominence of this component may be learning the language in the country where it is spoken. This implies two important motivational strategies for study abroad courses: the course syllabi should be tailored to the students' immediate needs and they should be provided with ample opportunities to practice Czech outside class and interact with locals - various field trips should be organised and autonomous tasks assigned as scaffolding to boost their confidence and experiment outside class on their own. More specific pedagogic implications 
for the American study abroad courses were proposed by Převrátilová, (2019, available on-line).

There are several limitations to this study. As was said in the introduction, the study presented here covers only the introduction to the ongoing larger-scale research that is still being carried out. So far, the American Study Abroad programme has been examined in more detail. The sample of Erasmus+ students in this study was very small, so more in-depth research needs to be done to portray the Erasmus+ students' motivation. Luisa and Luke are too small a sample to draw generalisable conclusions. There are remarkable similarities in their motivational profiles, namely the significant role of L2 Learning Experience, with emphasis on emotions connected to the classroom. The following stage of research should bring more details about the components of L2MSS in a broader scope and more insight into the generalisability of the hypothesis created by creating the motivational profiles of Luisa and Luke.

Additionally, there are methodological issues relating to the study limitations. The introspective methods used (diaries as well as interviews) may provide data that picture what the informants say about their learning process, not necessarily about how the process itself works or what they really think about it, particularly since the researcher was their teacher at the same time. In the following phase of the research, a broader scope of informants will be covered among students whose teacher is not the researcher.

Despite its limitations, the study contributed to the current discussion of language learning motivation as well as study abroad education. Bringing more insight into an area of motivational research that is still rather understudied (learning a language other than English, learning a small Slavic language) seems to be a fruitful learning direction of future research (Dörnyei \& Ushioda, 2017).

\section{Bibliography}

BAILEY, K. M., \& OCHSNER, R. (1983). A methodological overview of the diary studies: Windmill tilting or social science? In K. M. BAILEY, M. H. Long \& S. PECK (Eds.), Second Language acquisition studies (pp. 188-198). Boston: Heinle \& Heinle/Newbury House.

Boo, Z., DöRNYEI, Z., RYAN, S. (2015). L2 motivation research 2005-2014: Understanding publication surge and a changing landscape. System, 55, 147-157.

CARROLL, J. (1967). Foreign language proficiency levels attained by language majors near graduation from college. Foreign Language Annals, 1, 131-151.

Соoк, V. (2016). Premises of multi-competence. In V. CooK \& LI WEI (Eds.), The Cambridge handbook of linguistic multicompetence (pp. 1-25). Cambridge: Cambridge University Press.

DECI, E. L., RYAN, R. M. (1985). Intrinsic motivation and self-determination in human behavior. New York: Plenum.

DöRNYEI, Z. (2001). Motivational strategies in the language classroom. Cambridge: CUP. 
DöRNYEI, Z. (2005). The psychology of the language learner: Individual differences in second language acquisition. Mahwah, NJ: Lawrence Erlbaum.

DöRNYEI, Z. (2009). The L2 Motivational Self System. In Z. DöRNYEI \& E. UshiodA (Eds.), Motivation, language identity and the L2 self. Bristol: Multilingual Matters, 9-42.

DöRNYEI, Z. (2019). Towards a better understanding of the L2 Learning Experience, the Cinderella of the L2 Motivational Self System. Studies in Second Language Learning and Teaching, 9(1), 19-30.

DöRNYEI, Z., KuBANYOVA, M. (2014). Motivating learners, motivating teachers: building vision in the language classroom. Cambridge: CUP.

DöRNYEI, Z., UsHIODA E. (2011). Teaching and researching motivation. 2nd ed. Harlow: Longman.

DöRNYEI, Z., UshiodA, E. (2017). Beyond Global English: Motivation to Learn Languages in a Multicultural World: Introduction to the Special Issue. The Modern Language Journal, 101: 451-454.

DougLAS FIR Group (2016). A transdisciplinary framework for SLA in a multilingual world. Modern Language Journal, 100 (Supplement 2016), 19-47.

FRANCESCHINI, R. (2011). Multilingualism and multicompetence: A conceptual view. Modern Language Journal, 95, 344-355.

FREED, B., ED. (1995). Second language acquisition in a study abroad context. Amsterdam: John Benjamins.

GARDNER, R. (1985). Social psychology and second language learning: The role of attitudes and motivation. London: Edward Arnold.

GARDNER, R. (2009). Gardner and Lambert (1959): Fifty years and counting. Canadian Association of Applied Linguistics Symposium presentation, Ottawa, ON, May 2009.

GuilloteAuX, M., \& DöRNYEI, Z. (2008). Motivating Language Learners: A Classroom-Oriented Investigation of the Effects of Motivational Strategies on Student Motivation. TESOL Quarterly, 42(1), 55-77. Retrieved September 15, 2020, from http://www.jstor.org/stable/40264425

HENRY, A. (2017). L2 motivation and multilingual identities. Modern Language Journal, 101, 548-565.

KINGINGER, C. (2008). Language learning in study abroad: Case histories of Americans in France. Modern Language Journal Monograph Series, Vol. 1. Oxford: Blackwell.

Markus, H., Nurius, P. (1986). Possible selves. American Psychologist, 41(9), 954-969.

ORTEGA, L. (2013). SLA for the 21st century: Disciplinary progress, transdisciplinary relevance, and the bi/multilingual turn. Language Learning, 63 (Supplement 2013), 1-24.

PŘEvrátilová, S. (2020). Deníková studie o učení se češtině jako cizímu jazyku. Didaktické studie, 12(2), 127-145.

AuthoR, S. (2019). Should we make them study Czech while they study here? Change of Students' Attitudes towards Learning Czech during Study Abroad. Studie z aplikované lingvistiky. Praha: UK FF, 52-65.

SIEGLovÁ, D. (2008). Role jazykového postavení v adaptaci studentů z USA v české společnosti. In Etnické komunity v české společnosti, s. 84-104. Praha: Ermat.

\section{Author}

Silvie Převrátilová, Charles University, Faculty of Arts, e-mail: silvie.prevratilova@ff.cuni.cz

The author has been teaching English and Czech as foreign languages since her studies at the Faculty of Arts, Charles University, Prague. Her professional experience includes language teaching, teacher training, British Council exams, and material design. Currently, she works at Charles University training new teachers and teaching Czech to foreign students. She also runs methodology seminars and participates in creating new Czech language learning and teaching materials. Her main research interest is in the motivation to study Czech. 